\title{
PENGEMBANGAN LEMBAR KERJA SISWA BERBASIS PROBLEM BASED LEARNING PADA TOPIK IKATAN KIMIA
}

\author{
Ghery Priscylio $^{1 *}$, Parida Eriani $^{2}$, Ellizar $^{2}$ dan Andromeda ${ }^{2}$ \\ ${ }^{1}$ Pendidikan Ilmu Pengetahuan Alam, Sekolah Pascasarjana, Universitas Pendidikan \\ Indonesia, Jalan Setiabudhi No. 229 Kota Bandung Jawa Barat 40154 Indonesia \\ ${ }^{2}$ Pendidikan Kimia, Fakulltas Matematika dan Ilmu Pengetahuan Alam, Universitas Negeri \\ Padang, Jalan Prof. Dr. Hamka Air Tawar Kota Padang Sumatera Barat 25171 Indonesia \\ E-mail: ghery.priscylio@upi.edu
}

\begin{abstract}
ABSTRAK
Menguasai sains dan teknologi adalah kunci penting untuk menghadapi tantangan masa depan. Pendidikan sains memainkan peran penting dalam mempersiapkan siswa yang dapat berpikir kritis, kreatif, logis, dan mengambil inisiatif dalam memecahkan masalah. Penelitian ini bertujuan untuk menghasilkan lembar kerja siswa berbasis masalah pada topik ikatan kimia. Pada penelitian ini digunakan metode penelitian Research and Development $(R \& D)$ dengan model pengembangan 4-D yaitu terdiri dari tahap define, design, develop and disseminate. Instrumen pengumpulan data yang digunakan adalah lembar validasi dan angket praktikalitas. Lembar kerja yang dikembangkan divalidasi oleh enam orang ahli dan uji praktikalitas oleh 25 orang siswa SMA Negeri 1 Batang Kapas, Pesisir Selatan. Data yang diperoleh dianalisis dengan menggunakan Cohen's Kappa Formula. Uji validitas menyatakan lembar kerja siswa yang dikembangkan memiliki kategori validitas yang sangat tinggi. Uji praktikalitas siswa tentang lembar kerja siswa yang dikembangkan menunjukkan kategori yang sangat tinggi dan uji praktikalias guru memperoleh kategori kepraktisan yang sangat tinggi. Penelitian ini menyimpulkan bahwa lembar kerja pembelajaran berbasis masalah pada topik ikatan kimia adalah valid dan dapat digunakan dalam kegiatan pembelajaran. Temuan ini juga menunjukkan bahwa lembar kerja siswa yang dikembangkan dapat meningkatkan minat siswa untuk belajar dan dapat membantu siswa untuk belajar secara mandiri.
\end{abstract}

Kata kunci: lembar kerja siswa, ikatan kimia, problem based learning, model 4-D, pendidikan kimia

\begin{abstract}
Mastering Science and Technology is an important key to face the future challenges. Science education plays an important role of preparing students who can think critically, creatively, logically, and take the initiative in solving problems. This research aims to generate problem based learning worksheets on the topic of chemical bonding. Research and development was used as method of the study by 4-D stages model i.e define, design, develop, and disseminate. Instruments of data collection used is validation sheet and practicality questionnaire. The developed worksheet was validated by six experts and practicality test by 25 students Senior High School 1 of Batang Kapas, Pesisir Selatan. The data obtained were analyzed by using Cohen's Kappa Formula. The validity test of the developed student worksheet is in very high validity categories. The practicality test of
\end{abstract}


students about developed student worksheet indicated a very high category and teacher practicality obtain a very high practicality category. The research concludes that Problem Based Learning Worksheets on the Topic of Chemical Bonding is valid and can be used in learning activities. This finding also suggests that the developed student worksheet can increase students' interest to learn and can help students to learn independently.

Keywords: student worksheet, chemical bonding, problem based learning, 4-D Models, chemistry education

DOI: http://dx.doi.org/10.15575/jtk.v4i1.4085

\section{PENDAHULUAN}

Salah satu keberhasilan suatu bangsa dilihat dari bagaimana pendidikan mampu membentuk sumber manusia yang berkualitas (Lestari, 2012). Pada era globalisasi ini suatu bangsa dituntut untuk menyiapkan generasi yang mampu mengikuti perkembangan ilmu pengetahuan dan teknologi. Pendidikan adalah modal utama bagi suatu bangsa dalam upaya meningkatkan kualitas sumber daya manusia (Laili, 2014). Pendidikan memiliki tuntutan untuk selalu meningkatkan pengetahuan dalam rangka menciptakan teknologi baru, konsep baru, dan teori baru. Perkembangan tersebut juga membawa dampak pada proses pembelajaran di sekolah yang pada akhirnya akan membuat guru menjadi lebih kreatif dalam mengajar siswa (Harnugrawan \& Novita, 2012). Salah satu faktor yang menentukan keberhasilan dalam pembelajaran yaitu ketersediaan bahan ajar (Anwar, 2017). Bahan ajar merupakan bahan yang diperlukan dalam proses pembelajaran dapat berupa informasi, alat dan teks yang disusun secara sistematis (Prastowo, 2011). Keadaan di sekolah saat ini bahan ajar yang digunakan siswa masih sangat terbatas, tak jarang ditemui pada saat pembelajaran berlangsung satu buku digunakan untuk dua orang siswa (Priscylio et al., 2018).
Salah satu bahan ajar yang dapat digunakan dalam proses pembelajaran yaitu lembar kerja siswa (LKS) (Priscylio, 2015). Lembar kerja siswa adalah lembaran-lembaran berisi tugas yang harus dikerjakan oleh peserta didik (Majid, 2012). Salah satu mata pelajaran yang dipelajari di tingkat SMA yaitu mata pelajaran Kimia dianggap abstrak dan sulit bagi sebagian besar siswa. Ilmu kimia sebagai proses sains yang meliputi cara berpikir, sikap, dan langkah kegiatan ilmiah untuk memperoleh produk kimia, mulai dari mencari masalah, mengumpulkan fakta yang terkait dengan masalah, membuat asumsi, mengendalikan variabel, mengamati, mengambil pengukuran, penyimpulan, prediksi, mengumpulkan dan memproses data pengamatan atau pengukuran, dan untuk menyimpulkan dan mengkomunikasikan (Putri, 2016). Salah satu model pembelajaran yang dapat diterapkan dalam pembelajaran kimia yaitu pembelajaran berbasis masalah (problem based learning). Model pembelajaran berbasis masalah mendapat perhatian tinggi dari praktisi pendidikan (Taşoğlu \& Bakaç, 2014). Dalam pembelajaran berbasis masalah, siswa bekerja dalam kelompok kolaboratif belajar dengan menyelesaikan masalah yang kompleks dan realistis di bawah bimbingan guru (Allen et al., 2011). Pembelajaran berbasis masalah mendorong siswa untuk berpikir dan memecahkan masalah dalam kurun waktu tertentu, memberikan 

Kimia

pengalaman otentik yang menumbuhkan pembelajaran aktif, mendukung konstruksi pengetahuan, secara alami mengintegrasikan pembelajaran sekolah dan kehidupan nyata. Tujuan dari PBL adalah menerapkan pemikiran kritis, keterampilan pemecahan masalah, dan konten pengetahuan untuk masalah-masalah dunia nyata, untuk mengembangkan diri sendiri, reflektif, pembelajaran seumur hidup yang dapat mengintegrasikan pengetahuan, berpikir kritis, bekerja sama dengan orang lain (Taşoğlu \& Bakaç, 2014). Pandangan yang lebih komprehensif tentang pemikiran kritis mengacu pada disposisi, untuk menggambarkan kecenderungan seseorang untuk menggunakan pemikiran kritis ketika memecahkan masalah, mengevaluasi ide atau keputusan yang dibuat (Temel, 2014).

Oleh karena itu perlu dilakukan suatu pengembangan LKS yang dapat meningkatkan keterampilan belajar siswa dengan pola pikir yang terbuka, kritis dan aktif dalam proses pembelajaran salah satunya yaitu penggunaan LKS berbasis masalah. Pembelajaran berbasis masalah dapat dilakukan dengan beberapa langkah, yaitu menyadari masalah, merumuskan masalah, merumuskan hipotesis, mengumpulkan data, menguji hipotesis dan menentukan pilihan penyelesaian (Sanjaya, 2006). Penelitian ini bertujuan untuk mengembangkan LKS berbasis problem based learning pada topik Ikatan Kimia. Menurut silabus mata pelajaran kimia sesuai kurikulum 2013 materi ikatan kimia dipelajari di kelas X semester 1. Menurut silabus kurikulum 2013 mata pelajaran kimia pada topik ikatan kimia terdiri dari empat Kompetensi Dasar (KD) yaitu KD 3.5, KD 3.6, KD 3.7 dan KD 4.5 yang diturunkan menjadi indikator dan tujuan pembelajaran.
Pada topik ikatan kimia siswa akan mempelajari tentang proses terbentuknya ikatan dalam suatu unsur dan senyawa yaitu terdiri dari ikatan ion, ikatan kovalen, ikatan kovalen koordinasi dan ikatan logam. Selain itu siswa juga akan mempelajari interaksi antar partikel, hubungan jenis ikatan dengan sifat fisik suatu senyawa, menganalisis kepolaran dari suatu senyawa serta meramalkan bentuk molekul berdasarkan teori domain elektron. Sebagai materi prasyarat siswa harus memahami konfigurasi elektron dan struktur lewis.

\section{METODE PENELITIAN}

\subsection{Jenis Penelitian}

Penelitian ini menggunakan metode Research and Development $(R \& D) . R \& D$ adalah suatu proses mengembangkan produk baru atau menyempurnakan produk yang telah ada, yang mana semua kegiatannya dapat dipertanggungjawabkan. Menurut Sugiyono (2014) "Penelitian pengembangan adalah penelitian yang digunakan untuk menghasilkan produk tertentu dan menguji keefektifan produk tersebut". Menurut Nana Syaodih Sukmadinata "Penelitian $R \& D$ adalah proses atau langkah-langkah untuk mengembangkan atau menyempurnakan suatu produk baru maupun yang telah ada dan dapat dipertanggungjawabkan (Sukmadinata, 2009).

\subsection{Prosedur Penelitian}

Prosedur penelitian yang diterapkan pada penelitian ini adalah menggunakan model pengembangan yaitu model 4-D (four $D$ models) seperti yang dikembangkan oleh Thiagarajan, Semmel dan Semmel. Model 4- $D$ ini terdiri dari empat tahap utama yaitu: (1) define (pendefinisian), (2) design (perancangan), (3) develop (pengembangan) dan (4) disseminate (penyebaran) (Trianto, 

Kimia

2012). Uraian kegiatan-kegiatan yang akan dilakukan pada setiap tahap sebagai berikut:

\subsubsection{Tahap pendefinisian (define)}

Pelaksanaan penelitian ini di awali dengan tahap define. Pada tahap define dilakukan penetapan dan pendefinisian syarat-syarat pembelajaran. Langkah-langkah yang dilakukan pada tahap define ini meliputi:

\subsubsection{Analisis ujung depan}

Analisis ujung depan bertujuan untuk memunculkan dan menetapkan masalah dasar yang dihadapi dalam proses pembelajaran. Karena proses pembelajaran berpedoman kepada kurikulum 2013, maka analisis ujung depan dalam hal ini adalah menganalisis kurikulum 2013. Analisis kurikulum yang dilakukan yaitu dengan melihat proses pembelajaran yang terjadi di lapangan dan membandingkan dengan tuntutan kurikulum 2013.

\subsubsection{Analisis Siswa}

Analisis ini bertujuan untuk mengetahui subjek penelitian yaitu siswa kelas X MIA. yang dilakukan pada analisis siswa ini adalah melihat karakterstik dari siswa yang dijadikan subjek penelitian yaitu meliputi kemampuan akademik, motivasi belajar dan psikomotorik. Analisis siswa yang telah di lakukan pada siswa kelas $X$ di SMA Negeri 1 Batang Kapas Pesisir Selatan yang berusia 15-16 tahun.

\subsubsection{Analisis Tugas}

Pada analisis tugas dilakukan analisis terhadap KI dan KD yang akan dikembangkan menjadi LKS berbasis masalah. Pada penelitian ini yang dianalisis adalah KI dan KD pada topik ikatan kimia yang dipelajari di kelas X SMA sesuai silabus kurikulum 2013, sehingga didapatkan indikator dan tujuan pembelajaran yang akan dicapai. Selain itu bertujuan untuk mengidentifikasi dan menganalisis kemampuan yang harus diketahui siswa melalui penentuan isi dalam satuan pembelajaran yang sesuai dengan kurikulum 2013.

\subsubsection{Tahap Perancangan (Design)}

Tahap perancangan (design) merupakan tahapan merancang lembar kerja siswa (LKS) berbasis masalah pada topik ikatan kimia kelas X SMA/MA. Tahapan yang dilakukan adalah:

\subsubsection{Pemilihan Format}

Tahap ini dilakukan dengan pemilihan format bahan ajar yang sesuai dengan format penulisan LKS (Depdiknas, 2008). Format yang dimaksud adalah tampilan, sistematika penyampaian materi dan isi bahan ajar. Pada penelitian ini bahan ajar yang dipilih yaitu dalam bentuk LKS.

\subsubsection{Ada Perancangan LKS}

Pada tahap ini dirancang LKS sesuai dengan format penulisan LKS dalam buku panduan pengembangan bahan ajar dari Depdiknas tahun 2008. Berdasarkan hal ini akan dihasilkan LKS dengan menggunakan siklus pembelajaran berbasis masalah yaitu menyadari masalah, merumuskan masalah, merumuskan hipotesis, mengumpulkan data, menguji hipotesis dan menentukan pilihan penyelesaian (Sanjaya, 2006).

\subsubsection{Tahap Pengembangan (Develop)}

Pada tahap pengembangan dilakukan modifikasi produk yang dihasilkan pada tahap perancangan setelah mendapat masukan dan penyempurnaanpenyempurnaan dari para validator, sebelum menjadi produk akhir yang siap untuk dilakukan uji coba lapangan di sekolah target. Pada tahap ini terdapat 3 langkah, yaitu validasi (penilaian) produk, revisi dan uji coba. 


\subsubsection{Uji Validitas}

Uji validitas pada LKS berbasis masalah yang dihasilkan divalidasi oleh enam orang validator yaitu terdiri dari tiga orang dosen jurusan kimia FMIPA UNP dan tiga orang guru kimia. Validator diminta untuk memberikan penilaian dan saran terhadap LKS yang sudah dibuat baik dari segi isi, konstruk (penyajian), bahasa dan kegrafisan yang digunakan. Kritikan, masukan dan saran dari para validator menjadi bahan untuk merevisi LKS berbasis masalah yang sudah dibuat.

\subsubsection{Revisi}

Tahap revisi ini bertujuan untuk memperbaiki bahan ajar dalam bentuk LKS berbasis masalah sesuai dengan kritikan, masukan dan saran dari para validator sebelum produk diuji coba. LKS berbasis masalah yang sudah diperbaiki kemudian diberikan kembali kepada validator untuk didiskusikan lebih lanjut. Revisi dihentikan apabila validator sudah menyatakan LKS berbasis masalah yang dibuat sudah valid dan bisa diuji cobakan di lapangan.

\subsubsection{Uji coba}

Uji coba produk dilakukan pada siswa kelas $X$ di SMA Negeri 1 Batang Kapas Pesisir Selatan dalam jumlah terbatas. Uji coba ini bertujuan untuk mengetahui praktikalitas dari LKS berbasis masalah yang dibuat. Uji praktikalitas dilakukan untuk mengetahui sejauh mana manfaat, kemudahan penggunaan LKS berbasis masalah. Uji praktikalitas ini dilakukan dengan memberikan angket uji praktikalitas kepada guru kimia dan siswa SMA.

\subsubsection{Tahap Penyebaran (disseminate)}

Pada konteks pengembangan bahan ajar, peneliti pada tahap diseminasi ini membatasi hanya sampai tahapan sosialisasi bahan ajar melalui pendistribusian dalam jumlah terbatas kepada guru dan siswa untuk memperoleh respon terhadap bahan ajar yang sudah dihasilkan. Apabila respon sasaran pengguna bahan ajar sudah baik, maka baru dilakukan pencetakan dalam jumlah banyak dan pemasaran supaya bahan ajar itu dapat digunakan oleh sasaran yang lebih luas. Namun peneliti tidak melakukan percetakan dalam jumlah banyak dan pemasaran karena keterbatasan waktu dan biaya.

\subsubsection{Instrumen Penelitian}

Untuk mengumpulkan data penelitian, digunakan instrumen pengumpul data. Instrumen yang digunakan dalam penelitian ini adalah:

\subsection{Lembar Validasi LKS Berbasis Masalah}

Lembar validasi bahan ajar berbasis masalah dalam bentuk LKS yang digunakan untuk menilai validitas isi dan validasi konstruk dari bahan ajar dalam bentuk LKS berbasis masalah yang dihasilkan. Data yang didapat digunakan untuk mengungkapkan tingkat validitas LKS berbasis masalah yang dikembangkan.

\subsection{Angket}

Angket yang diberikan merupakan angket respon siswa dan respon guru terhadap LKS berbasis masalah yang digunakan selama proses pembelajaran berlangsung. Data angket dimaksudkan untuk mengetahui tingkat praktikalitas pemakaian LKS berbasis masalah selama proses pembelajaran.

\subsubsection{Teknik Analisis Data}

\subsection{Teknik Analisis Validitas}

Penilaian validator terhadap masing-masing pernyataan dianalisis dengan menggunakan formula kappa Cohen, dimana pada akhir pengolahan diperoleh momen kappa. 

Kimia

$$
\text { Momen kappa }(k)=\frac{P-P e}{1-P e}
$$

\section{Keterangan:}

$\mathrm{k}=$ momen kappa yang menunjukkan validitas produk

$\mathrm{P}=$ proporsi yang terealisasi, dihitung dengan cara jumlah nilai yang diberi oleh validator dibagi jumlah nilai maksimal

$\mathrm{Pe}=$ proporsi yang tidak terealisasi, dihitung dengan cara jumlah nilai maksimal dikurangi dengan jumlah nilai total yang diberi validator dibagi jumlah nilai maksimal (Boslaugh \& Andrew Watters, 2008).

Tabel 1. Kategori Keputusan berdasarkan Momen Kappa (k)

\begin{tabular}{|c|c|}
\hline Interval & Kategori \\
\hline $0,81-1,00$ & sangat tinggi \\
\hline $0,61-0,80$ & tinggi \\
\hline $0,41-0,60$ & sedang \\
\hline $0,21-0,40$ & rendah \\
\hline $0,01-0,20$ & sangat rendah \\
\hline 0,00 & tidak valid \\
\hline
\end{tabular}

\subsubsection{Teknik Analisis Kepraktisan}

Teknik analisis kepraktisan sama halnya dengan teknik analisis validitas maka penilaian lembar praktikalitas diperoleh dari pemberian angket respon guru dan angket respon siswa yang juga dianalisis dengan menggunakan formula kappa Cohen.

\section{HASIL DAN PEMBAHASAN}

\subsection{Uji Validitas}

Validitas adalah penilaian suatu produk. Suatu produk dikatakan valid jika instrumen dapat mengukur apa yang harus diukur (Latisma, 2011; Sukardi, 2012). Validasi produk dapat dilakukan oleh beberapa ahli berpengalaman atau ahli untuk menilai kelebihan dan kekurangan produk baru yang dihasilkan (Sugiyono, 2014). Produk ini divalidasi oleh enam validator yaitu tiga orang dari dosen jurusan kimia FMIPA Universitas Negeri Padang dan tiga orang guru kimia yaitu satu orang guru kimia SMA Negeri 2 x 11 Enam Lingkung Kayu Tanam dan dua orang guru kimia SMA Negeri 1 Batang Kapas Pesisir Selatan. Validator memberikan penilaian terhadap LKS berbasis problem based learning yang dikembangkan dengan mempertimbangkan empat aspek, yaitu komponen isi, komponen konstruksi (komponen penyajian), komponen kebahasaan dan komponen kegrafisan (Arikunto, 2008; Depdiknas, 2008) (Rochmad, 2011). Nilai momen kappa (k) Uji Validiasi dapat di lihat pada Gambar 1. Dari hasil perhitungan momen kappa uji validitas dapat dilihat bahwa nilai momen kappa ( $k$ ) yang diberikan oleh enam orang validator memperoleh nilai pada rentang tinggi dan sangat tinggi jika merujuk pada kategori keputusan yang terdapat pada Tabel 1 .

Jika nilai momen kappa $(\mathrm{k})$ dari 6 orang validator kita rata-rata kan maka didapatkan data seperti yang terdapat pada Tabel 2. Pada komponen isi memperoleh nilai momen kappa 0,84 dengan kategori sangat tinggi, komponen konstruk 0,8 dengan kategori tinggi dan komponen kebahasaan dan kegrafisan 0,86 dengan kategori sangat tinggi.

\subsection{Uji Praktikalitas}

Uji praktikalitas diberikan kepada guru dan siswa. Pada penelitian ini uji praktikalitas diujikan kepada 3 orang guru kimia dan kepada 25 orang siswa kelas X SMA Negeri 1 Batang Kapas. Uji praktikalitas bertujuan untuk mengetahui kepraktisan penggunaan dari bahan ajar yang telah dikembangkan yang pada penelitian ini yaitu berupa LKS 


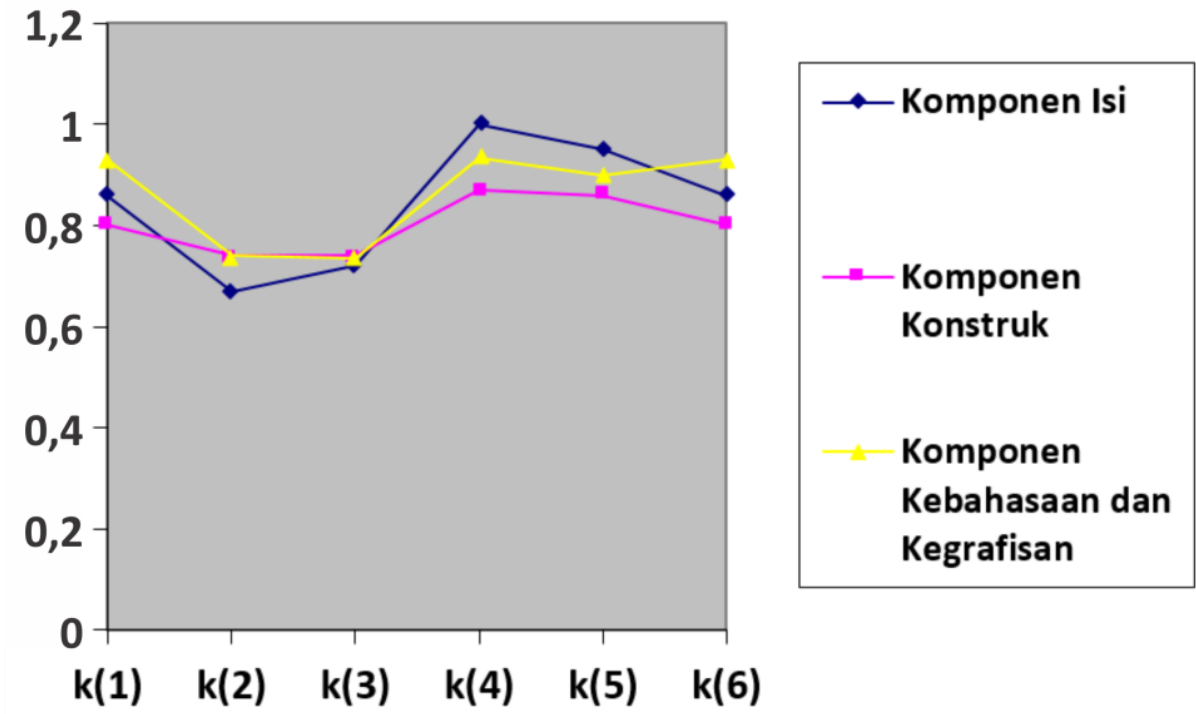

Gambar 1. Nilai Momen Kappa (k) Uji Validitas

berbasis $P B L$ oleh guru dan siswa. Guru dan siswa diberikan LKS yang telah dikembangkan dan diminta untuk mengisi angket respon guru dan angket respon siswa yang menanyakan pandangan mereka terkait kepraktisan penggunaan LKS yang telah dikembangkan. Hasil dari angket respon guru dan angket respon siswa juga dianalisis menggunakan formula momen kappa. Menurut Mudjijo suatu Instrumen yang baik adalah instrumen yang dapat dengan mudah diimplementasikan dan diinterpretasikan hasilnya (Mudjijo, 1995). Jadi suatu bahan ajar atau produk yang bagus adalah produk yang mudah digunakan oleh guru dan siswa dalam proses pembelajaran kimia. Berdasarkan hasil pengolahan data angket respon guru dan angket respon siswa tentang praktikalitas LKS yang dikembangkan dapat dilihat pada Tabel 2.

Tabel 2. Nilai Rata-rata Momen Kappa (k) Uji Praktikalitas

\begin{tabular}{|c|c|}
\hline Uji Praktikalitas & $\begin{array}{c}\text { Nilai Rata - rata } \\
\text { Momen Kappa (k) }\end{array}$ \\
\hline Angket Respon Guru & 0,92 \\
\hline Angket Respon Siswa & 0,89 \\
\hline
\end{tabular}

Berdasarkan hasil rata - rata (k) angket respon guru dan angket respon siswa pada Tabel 2 dapat disimpulkan bahwa uji praktikalitas LKS yang dikembangkan memiliki kategori sangat tinggi.

\subsection{Tampilan Bahan Ajar}

Tampilan LKS yang dikembangkan dapat dilihat pada Gambar 2, 3, 4 dan 5.

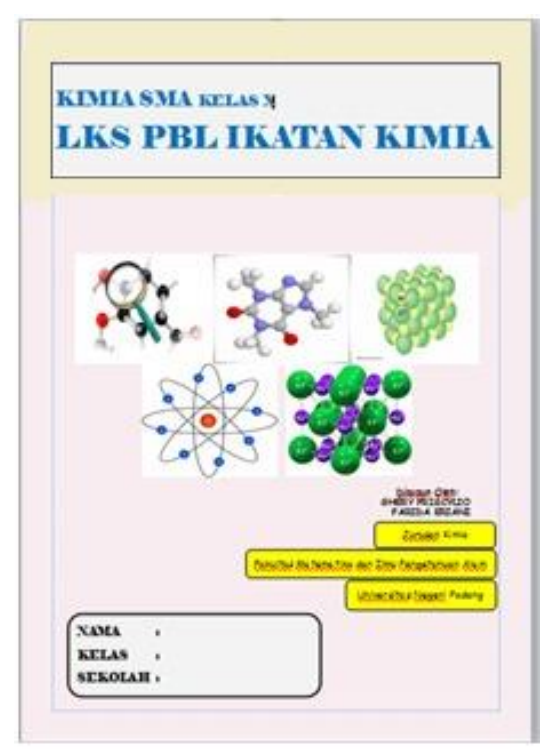

Gambar 2. Sampul LKS yang dikembangkan 

Kimia

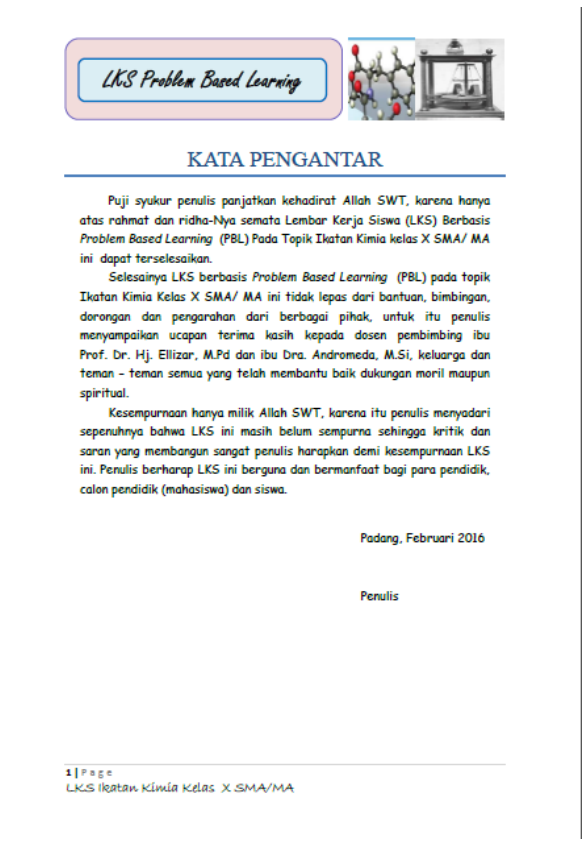

Gambar 3. Kata Pengantar

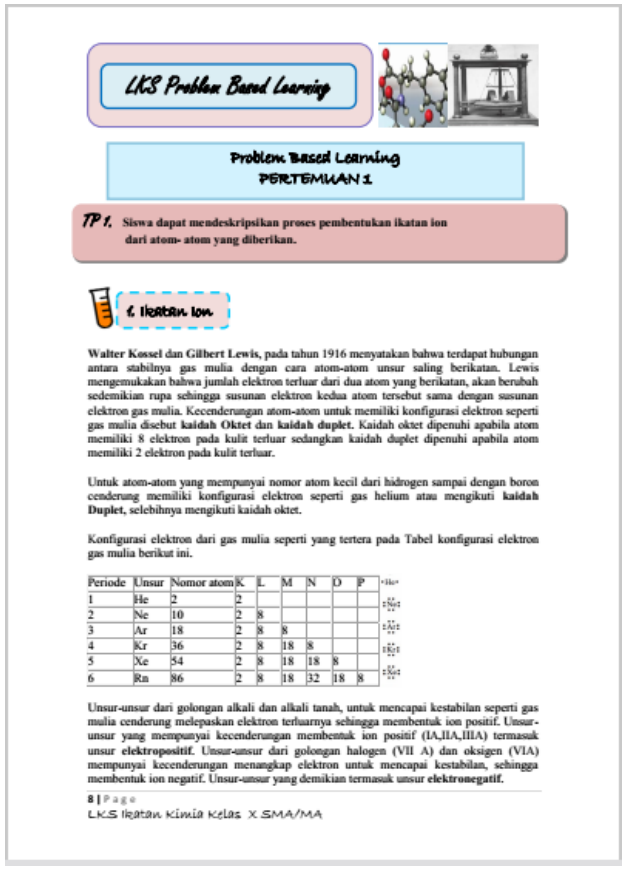

Gambar 4. Tampilan Pertemuan 1

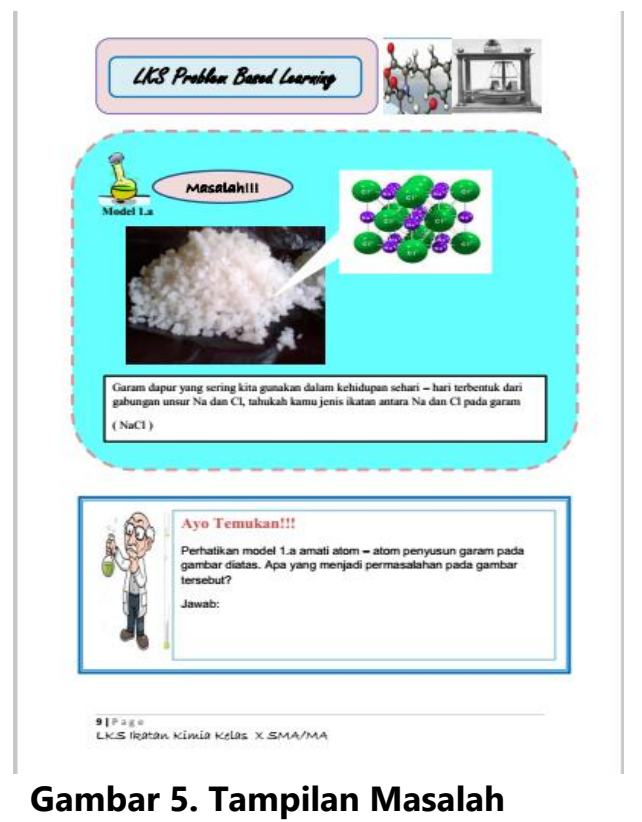

\section{KESIMPULAN}

Berdasarkan penelitian yang telah dilakukan maka dihasilkan LKS berbasis PBL yang memilki validitas sangat tinggi. Pada komponen isi, komponen kebahasaan dan kegrafisan memiliki kategori momen kappa yang sangat tinggi dan pada komponen konstruk memiliki kategori momen kappa tinggi. Selain itu LKS yang telah dikembangkan memilki praktikalitas yang sangat tinggi yang diketahui dari hasil uji praktikalitas kepada guru dan siswa. Temuan ini menunjukkan bahwa LKS berbasis PBL yang dikembangkan dapat meningkatkan minat belajar siswa dan dapat membantu siswa untuk belajar secara mandiri karena bahan ajar ini dapat dipahami dan digunakan dengan baik. 

Kimia

\section{DAFTAR PUSTAKA}

Allen, D. E., Donham, R. S., \& Bernhardt, S. A. Changes for Junior High School. Unesa Journal of Chemical Education, 1(1), 4146.

(2011). Problem-Based Learning. New Direction for Teaching and Learning, (128), 21-29.

Anwar, S. (2017). Pengolahan Bahan Ajar. Bandung: Universitas Pendidikan Indonesia.

Arikunto, S. (2008). Dasar-Dasar Evaluasi Pendidikan. Jakarta: Bumi Aksara.

Boslaugh, S., \& Andrew Watters, P. (2008). Statistics in a Nutshell a Desktop Quick Reference. United State of America: O'Reilly Media, Inc.

Depdiknas. (2008). Pengembangan Bahan Ajar. Jakarta: Departemen Pendidikan Nasional, Direktorat Jenderal Manajemen Pendidikan Dasar dan Menengah, Direktorat Pembinaan Sekolah Menengah Atas.

Harnugrawan, G. O., \& Novita, D. (2012). The Assessment of Students Mind Mapping Result on Limited Trial Towards Bilingual Interactive E- Book Media Through Mind Mapping Strategy on Chemical Bonding Matter For SMA RSBI. Unesa Journal of Chemical Education, 1(1), 115-123.

Laili, U. (2014). Development of Student Worksheet Oriented to Concept Map on Chemical Bonding Matter Class X. Unesa Journal of Chemical Education, 3(2).

Latisma. (2011). Evaluasi Pendidikan. Padang: UNP Press.

Lestari, A. (2012). Development of Sciencechemitry Student Workheet Oriented Somatic, Auditory, Visual, and Intellectual (SAVI) in The Topic Matter 
Pendidikan. Bandung: Alfa Beta.

Sukardi. (2012). Evaluasi Pendidikan, Prinsip, Dan Operasionalnya. Jakarta: Bumi Aksara.

Sukmadinata, N. S. (2009). Metode Penelitian Pendidikan. Bandung: PT. Remaja Rosdakarya.

Taşoğlu, A. K., \& Bakaç, M. (2014). The Effects of Problem Based Approach on Student's Conceptual Understanding in Teaching of Magnetism Topics. Eurasian J. Phys. Chem. Educ, 6(2), 110-122.

Temel, S. (2014). The Effects of ProblemBased Learning on Pre-Service Teachers' Critical Thinking Dispositions and Perceptions of Problem-Solving Ability. South African Journal of Education, 34(1), 1-20.

Trianto. (2012). Model Pembelajaran Terpadu. Jakarta: Bumi Aksara. 